Scientia Marina 77(1)

March 2013, 69-79, Barcelona (Spain)

ISSN: 0214-8358

doi: $10.3989 /$ scimar.03656.21D

\title{
Catch of pelagic hauls in Mediterranean acoustic surveys: Is it the same between day and night?
}

\author{
ATHANASSIOS MACHIAS ${ }^{1}$, MYRTO M. PYROUNAKI ${ }^{1}$, IOLE LEONORI ${ }^{2}$, \\ GUALTIERO BASILONE ${ }^{3}$, MAGDALENA IGLESIAS ${ }^{4}$, ANDREA DE FELICE ${ }^{2}$, \\ ANGELO BONANNO ${ }^{5}$ and MARIANNA GIANNOULAKI ${ }^{1}$
}

\footnotetext{
${ }^{1}$ Hellenic Centre for Marine Research, Institute of Marine Biological Resources, Agios Kosmas, 16610 Elliniko, Athens, Greece. E-mail: amachias@hcmr.gr

${ }^{2}$ Istituto di Scienze Marine, Consiglio Nazionale delle Ricerche, Largo Fiera della Pesca, 60125 Ancona, Italy.

${ }^{3}$ Istituto per l'Ambiente Marino Costiero, Consiglio Nazionale delle Ricerche, Mazara del Vallo, via L. Vaccara 61, 91026 Mazara del Vallo (TP), Italy.

${ }^{4}$ Instituto Español de Oceanografia, Centro Oceanográfico de Baleares, Muelle de Poniente s/n, 07015 Palma de Mallorca, Baleares, España.

${ }^{5}$ Istituto per l'Ambiente Marino Costiero, Consiglio Nazionale delle Ricerche, Capo Granitola, 91021 Campobello di Mazara (TP), Italy.
}

\begin{abstract}
SUMMARY: Fish sampling is a critical aspect of acoustic surveys, because it is directly related to the "transformation" of echo into species biomass and subsequently affects the accuracy of acoustic estimates. In the present study, we investigated the differences between day and night sampling in a) the catch composition through certain diversity indices and b) the length frequency distribution of anchovy and sardine using catch data of pelagic hauls collected from four different regions of the European Mediterranean waters. In addition, the possible bias in trawl efficiency due to sampling time and the possible error introduced in acoustic estimates were investigated. No statistically significant differences were found between day and night in any of the parameters examined. The results showed that a more flexible strategy can be adopted to reduce the duration and the cost of acoustic sampling for small pelagic species. The advantages and disadvantages of the two sampling strategies are discussed.
\end{abstract}

Keywords: acoustic, pelagic hauls, day-night sampling, Mediterranean Sea, anchovy, sardine.

RESUMEN: Capturas de pescas pelágicas en campañas acústicas en el MediterRáneo: ¿Hay diferencias entre día y NOCHE? - El muestreo de las pescas pelágicas llevado a cabo durante las campañas acústicas es fundamental, debido a que se encuentra directamente relacionado con la "transformación" de los ecos detectados por la ecosonda en biomasa de peces pelágicos y, por consiguiente, afecta a la exactitud de las estimaciones acústicas. En el presente estudio, hemos investigado las diferencias existentes entre las pescas realizadas durante el día y durante la noche, por lo que se refiere a a) la composición de especies de la captura a través de ciertos índices de diversidad y, b) la distribución de frecuencia de tallas de la anchoa y de la sardina, basándonos en los datos de captura con artes de arrastre pelágico llevados a cabo en cuatro regiones distintas del mar Mediterráneo. Por otra parte, también se ha investigado el posible sesgo atribuido a la hora del día en que se ha llevado a cabo el muestreo, por lo que se refiere a eficiencia de la pesca, así como el posible error introducido en las estimaciones acústicas. No se han encontrado diferencias estadísticas significativas entre día y noche para ninguno de los parámetros examinados. Los resultados mostraron que se puede llevar a cabo una estrategia de pescas más flexible, que reduzca la duración y el costo de las campañas acústicas para pequeños pelágicos. Se discuten, asimismo, las ventajas y desventajas entre las dos estrategias de muestreo (diurna y nocturna).

Palabras clave: campañas acústicas, arrastre pelágico, muestreo día-noche, mar Mediterráneo, anchoa, sardina. 


\section{INTRODUCTION}

Hydroacoustic surveys are widely used as a direct method for biomass estimation and stock assessment of small pelagic fish. Biomass estimates at age based on acoustics are used as a tuning index in several stock assessment models in the Mediterranean (SGMED 2009, 2010) as well as in the Atlantic (ICES 2009). In the Mediterranean, landings of the main small pelagic target species (i.e. anchovy and sardine) indicate that they rarely exceed three years of age (Basilone et al. 2004, SGMED 2009, 2010). Experimental pelagic haul sampling is closely associated with acoustic surveys in order to obtain the length frequency distribution of the local fish populations, allocate recorded echoes to the catch composition and "transform" echo into biomass and number of individuals (Simmonds and MacLennan 2005). Consequently, suitable fish sampling is critical, since it directly affects the accuracy of acoustic estimates of target species. It has to fulfil the need to obtain representative and unbiased length-frequency distribution of the target species population as well as to provide a representative and unbiased estimate of the species composition at sea, especially in the case of unknown species associations.

In addition, acoustic surveys are often carried out over extended areas in order to cover the main distribution of a stock, involving increased cost in terms of time at sea, which often exceeds 40 days. To overcome these difficulties, investigating and adapting flexible research strategies becomes essential. For example, working in both daytime and night-time can significantly reduce survey time in many cases.

The effect of the time of day on acoustic and biological data sampling is an issue that has raised several contradictions regarding the introduction of error in abundance estimates (Iglesias et al. 2003, Zwolinski et al. 2007). The latter largely depends on parameters related to species behaviour. Small pelagics are known to exhibit diel vertical migrations, form dense schools during daytime composed of individuals of the same swimming ability (i.e. the same size), and disperse forming loose aggregations during night-time (Woodhead 1966, Azzali et al. 1985, Massè 1996, Freon and Misund 1999; Giannoulaki et al. 1999, Szcucka 2000, Zwolinski et al. 2007, Tsagarakis et al. 2012). This diurnal behaviour of fish schools makes fish either unavailable to the acoustic apparatus or difficult to distinguish acoustically from other scatterers, which could generate a degree of bias in the echo density used for abundance estimates (ICES 2005). According to this behaviour, differences in trawl selectivity between day and night are likely to occur, raising the question of what is the most appropriate sampling time to obtain representative samples of fish populations at sea in terms of both species and length composition.

Within the framework of the present study, we investigated the differences in the catch composition between day and night using catch data from pelagic trawls collected during acoustic surveys from four different regions of the European Mediterranean waters: the Iberian coast, the western part of the Adriatic Sea, the Strait of Sicily and the Aegean Sea. Day-time and night-time pairs of pelagic hauls from historical acoustic surveys and from targeted acoustic surveys were selected according to a specific common protocol for all regions. Special concern was given to the hauls that were held in the same geographic position during day and night-time. Comparisons involved certain diversity indices and the length-frequency distribution of anchovy and sardine, the main small pelagic species in the Mediterranean Sea. Finally, the trawl efficiency during day and night and the possible bias in acoustic estimates was examined and the advantages and disadvantages of the two sampling strategies are discussed.

\section{MATERIALS AND METHODS}

\section{Sampling description}

In the framework of acoustic surveys, pelagic hauls are routinely used to collect representative fish samples of the insonified echoes. In the present work we used catch data from hauls carried out within acoustic surveys in the Aegean Sea, the western part of the Adriatic Sea, the Strait of Sicily, and Spanish Mediterranean waters (Fig. 1). A description of the hauls used from each area is presented in Table 1. Tow speeds averaged 3.5 knots (range 2.5-4.5 knots) and tow length was approximately 2 nautical miles $(\mathrm{nm})$. All items in the catch were sorted to species level. Length measurements were made to $0.5 \mathrm{~cm}$ accuracy. In order to study the differences between day and night sampling, we used samples from targeted experimental hauls and hauls from historical surveys in the study areas based on a common protocol. The groups of hauls contained replicate hauls at the same site during day and night. Comparisons between day and night were done regarding species composition and length frequency.

Specifically, day-night haul group selection was based on:

- hauls that were held at the same site, within the range of maximum $3 \mathrm{~nm}$ distance

- hauls that were carried out at the same site within a maximum period of $32 \mathrm{~h}$ replicate availability in both daytime and night-time hauls

- hauls that collected all replicates using the same gear, i.e. pelagic trawl with the same technical characteristics.

Comparisons were made by area between daytime and night-time haul groups. In addition, in cases in which more than one group of day-night hauls occurred within the same survey, an additional comparison was made between daytime and night-time hauls on a survey basis. These results are presented separately. The analysis scheme is summarized in Figure 2.

Specifically,

- North Aegean Sea: 22 groups of day-night pairs derived from 11 surveys were used for the species 


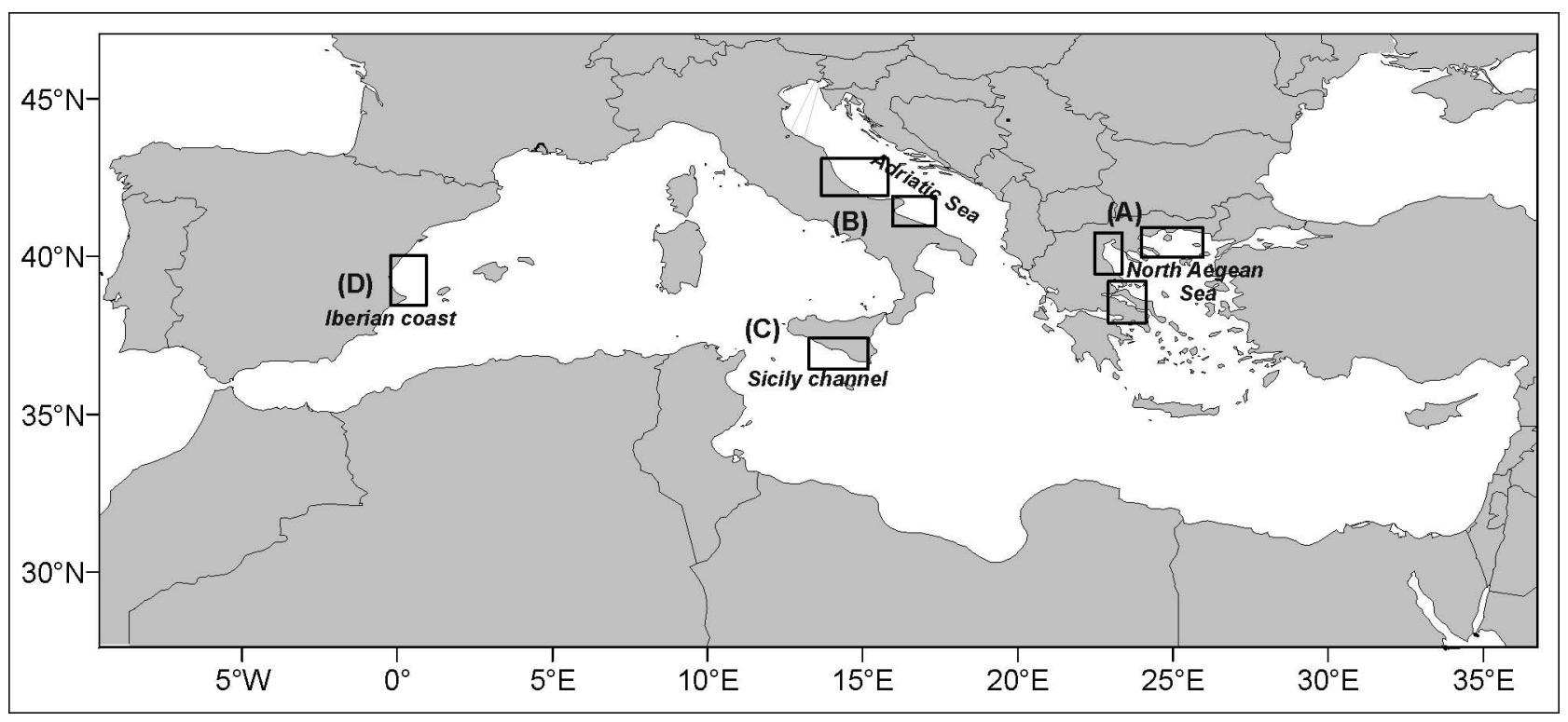

FIG. 1. - The areas and sites of sampling used in the analysis.

composition comparison. The surveys were conducted in the northern Aegean Sea on board the R/V Philia. Two surveys took place in winter (December, February) and nine in summer (June, July). Sixteen groups of day-night pairs derived from 10 surveys were used for the length-frequency distribution of anchovy and 14 groups distributed in 10 surveys were used for that of sardine. Four groups of hauls derived from targeted

TABLE 1. - Description of samples.

\begin{tabular}{|c|c|c|c|c|c|c|}
\hline \multirow[t]{2}{*}{ Area } & \multirow[t]{2}{*}{ Year/Season } & \multirow[t]{2}{*}{ Group } & \multirow[t]{2}{*}{ Date } & \multirow[t]{2}{*}{ Bottom depth } & \multicolumn{2}{|c|}{ No of hauls } \\
\hline & & & & & Day & Night \\
\hline \multirow[t]{22}{*}{ Aegean Sea } & 1995 Summer & 1 & $14 / 06 / 1995$ & 84 & 2 & 4 \\
\hline & 1996 Summer & 1 & $13 / 06 / 1996$ & 60 & 2 & 2 \\
\hline & 2003 Summer & 1 & $15 / 06 / 2003$ & 40 & 2 & 2 \\
\hline & 2004 Summer & 1 & $14 / 06 / 2004$ & 45 & 2 & 2 \\
\hline & 2005 Summer & 1 & $05 / 06 / 2005$ & 50 & 2 & 3 \\
\hline & 2005 Summer & 2 & $11 / 06 / 2005$ & 46 & 2 & 2 \\
\hline & 2005 Summer & 3 & $12 / 06 / 2005$ & 38 & 2 & 2 \\
\hline & 2005 Summer & 4 & $29 / 06 / 2005$ & 57 & 2 & 2 \\
\hline & 2006 Summer & 1 & $28 / 05 / 2006$ & 76 & 2 & 2 \\
\hline & 2006 Summer & 2 & $31 / 05 / 2006$ & 76 & 2 & 2 \\
\hline & 2006 Summer & 3 & $02 / 06 / 2006$ & 68 & 2 & 2 \\
\hline & 2006 Summer & 4 & $12 / 06 / 2006$ & 90 & 2 & 2 \\
\hline & 2006 Summer & 5 & $13 / 06 / 2006$ & 47 & 2 & 2 \\
\hline & 2006 Summer & 6 & $29 / 06 / 2006$ & 30 & 2 & 2 \\
\hline & 2008 Summer & 1 & $13 / 06 / 2008$ & 66 & 2 & 2 \\
\hline & 2008 Summer & 2 & $18 / 06 / 2008$ & 64 & 2 & 3 \\
\hline & 2008 Summer & 3 & $14 / 07 / 2008$ & 79 & 2 & 2 \\
\hline & 2008 Summer & 4 & $16 / 07 / 2008$ & 28 & 2 & 3 \\
\hline & 2008 Summer & 1 & $19 / 07 / 2008$ & 30 & 6 & 3 \\
\hline & 2007 Summer & 1 & $30 / 07 / 2007$ & 65 & 7 & 4 \\
\hline & 2007 Winter & 1 & $11 / 12 / 2007$ & 50 & 7 & 6 \\
\hline & 2009 Winter & 1 & $13 / 02 / 2009$ & 50 & 5 & 5 \\
\hline \multicolumn{7}{|c|}{ Western Adriatic Sea } \\
\hline Mafredonia & 2009 Summer & 1 & 09/08/2009 & 29 & 2 & 2 \\
\hline Mafredonia & 2009 Summer & 2 & $10 / 08 / 2009$ & 29 & 2 & 2 \\
\hline Vasto & 2009 Summer & 3 & $11 / 08 / 2009$ & 50 & 2 & 2 \\
\hline Vasto & 2009 Summer & 4 & $12 / 08 / 2009$ & 50 & 2 & 2 \\
\hline San Benedetto & 2009 Autumn & 5 & $30 / 09 / 2009$ & 80 & 2 & 2 \\
\hline San Benedetto & 2009 Autumn & 6 & $01 / 10 / 2009$ & 80 & 2 & 2 \\
\hline Barletta & 2010 Summer & 7 & $21 / 07 / 2010$ & 100 & 2 & 2 \\
\hline Barletta & 2010 Summer & 8 & $22 / 07 / 2010$ & 100 & 2 & 2 \\
\hline \multicolumn{7}{|l|}{ Strait of Sicily } \\
\hline Gulf of Gela & 2010 Summer & 1 & $01-02 / 08 / 2010$ & 40 & 2 & 2 \\
\hline Gulf of Gela & 2010 Summer & 2 & $02-03 / 08 / 2010$ & 70 & 2 & 2 \\
\hline \multicolumn{7}{|l|}{ Iberian coast } \\
\hline Cape La Nao & 2009 Summer & 1 & $13 / 08 / 2009$ & 81 & 3 & 3 \\
\hline
\end{tabular}



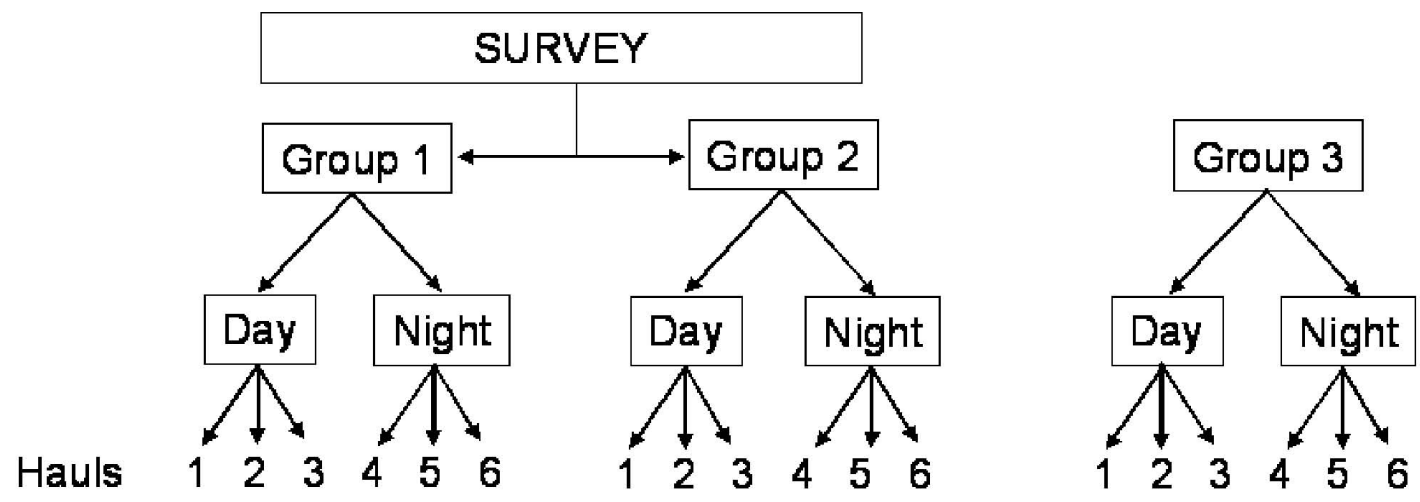

FIG. 2. - The scheme of the analysis

surveys and the others were selected from historical surveys according to the common protocol. In all cases fish sampling was conducted by means of a pelagic trawl with a codend of $16 \mathrm{~mm}$ mesh size.

- Adriatic Sea: Eight groups of day-night pairs were used for species composition and length frequency comparison. The data were collected within four targeted surveys (three in 2009 and one in 2010). Within each survey, two hauls were repeated three times, initially during daytime, once during the night and a third time during the day after. The surveys took place from July to October in Manfredonia Gulf, Barletta (southern Adriatic Sea), Vasto and San Benedetto (middle Adriatic Sea). All surveys were conducted on board the R/V G. Dallaporta using a pelagic trawl with codend of $18 \mathrm{~mm}$ mesh size.

- Strait of Sicily: Two groups of day-night pairs were used for species composition and length frequency comparison. Data were collected within one targeted survey carried out in August 2010. The survey was conducted in the Gulf of Gela on board the R/V Maria Grazia. A pelagic trawl with a codend of $18 \mathrm{~mm}$ mesh size was used for fish sampling. The area was selected because of the local occurrence of high fish density. Similarly to the targeted surveys in the Adriatic Sea within the survey, two hauls were repeated three times, initially during daytime, once during the following night and a third time during the following day.
- Iberian coast: One group of day-night pairs was used for species composition and length frequency comparison on the Iberian continental shelf. Data were collected during the 2009 acoustic survey in the area of Cape La Nao in June 2009 within targeted hauls. The survey was conducted on board the R/V Cornide de Saavedra. A pelagic trawl with a codend of $20 \mathrm{~mm}$ mesh size was used for fish sampling. Within the survey three hauls were repeated during daytime and night-time.

\section{Comparison of species composition between day and night}

The species caught in each area are presented in Table 2. In order to examine any possible differences in the catch between day and night, we compared the following diversity indices from the paired groups of hauls: number of species $(S)$; species richness (Margalef) $d=(S-1) / \log (N) \quad(\mathrm{N}$, number of individuals); Shannon-Wiener diversity

$$
H=-\sum_{i} P_{i} \ln \left(P_{i}\right)
$$

( $P$ is the percentage of individual of species $i$ ); $J$-evenness indices $J=H / \log S$; as well as the Simpson index

$$
1-\lambda=1-\sum \frac{N_{i}\left(N_{i}-1\right)}{N(N-1)}(\text { Clarke and Warwick 1994). }
$$

TABLE 2. - Species composition of the pelagic community in each sampling area.

\begin{tabular}{llll}
\hline Aegean Sea & Western Adriatic Sea & Strait of Sicily & Iberian coast \\
\hline Engraulis engrasicolus & Alosa fallax & Engraulis encrasicolus & Engraulis encrasicolus \\
Micromesistius poutassou & Aphia minuta & Boops boops & Sardina pilchardus \\
Sardina pilchardus & Boops boops & Sardina pilchardus & Scomber colias \\
Sardinella aurita & Engraulis encrasicolus & Sardinella aurita & Scomber scombrus \\
Scomber colias & Sardina pilchardus & Scomber colias & Trachurus mediterraneus \\
Scomber scombrus & Sardinella aurita & Scomber scomber & Spicara smaris \\
Spicara smaris & Scomber colias & Spicara maena & \\
Trachurus mediterraneus & Scomber scomber & Trachurus mediterraneus \\
Trachurus trachurus & Seriola dumerili & Trachurus trachurus \\
& Spicara maena & & \\
& Spicara smaris & & \\
& Sprattus sprattus & \\
& Trachurus mediterraneus & \\
& Trachurus trachurus & \\
\hline
\end{tabular}


In the case of the $J$ index, the sample size is standardized in respect to abundance and species number, while the Simpson index (i.e. dominance), is known to be one of the indices least affected by sample size (Karakassis et al. 1996).

The comparison of the estimated diversity indices between day and night samples was made using the analysis of variance (ANOVA) after checking for the homogeneity of variance (Zar 1984). The diversity indices were estimated using the PRIMER-5 software (Clarke and Warwick 1994).

\section{Comparison of length frequencies between day and night}

We investigated the possible differences in the length frequency distribution of the specimens caught in daytime and night-time samples. Comparisons refer to the length frequency distribution of anchovy and sardine, the two main small pelagic species that are the targets of the MEDIAS (MEDIterranean Acoustic Survey) acoustic surveys in the Mediterranean Sea. A Kruskal-Wallis test was used for this purpose. The geometric mean was selected to calculate the mean fish size of each sample, instead of the arithmetic mean which is susceptible to the influence of a few large specimens and does not accurately represent the mode in fish size at a given station (Stefanescu et al. 1992).

In addition, a paired-sample comparison analysis was applied to the mean, min, max, range, skewness and kurtosis of the total length (TL) distribution of the specimens caught during daytime and night-time in order to investigate the randomness or the possible bias in the abovementioned results.

\section{Comparison of trawl efficiency during daytime and night-time}

In order to obtain an indication regarding the possible bias of fishing during daytime and night-time, the trawl efficiency was estimated according to the approach described by Doray et al. (2010). For this purpose we used the available trawl data from monospecific hauls (i.e. one species contributed over $95 \%$ to the total catch) that were simultaneously insonified. Thus, we used 13 daytime hauls and 23 night-time hauls. In 25 cases (9 daytime and 16 night-time) anchovy contributed over $95 \%$ to the total catch, while in the rest of the hauls sardine dominated the catch in the same proportion.

Volume backscattering coefficients (MacLennan et al. 2002) greater than $-60 \mathrm{~dB}$ obtained with a 38 $\mathrm{kHz}$ split beam echosounder were allocated to fish and integrated with Myriax Echoview software to estimate nautical area scattering coefficients (NASCs). Specifically during both day and night, backscattering echo was integrated using an elementary sampling unit (ESU) of $500 \mathrm{~m}$ (or $0.25 \mathrm{~nm}$ ) length at a mean speed of 3.5 knots. The values of fish backscattering echo were then summed over each ESU at the depth range sampled by the pelagic trawl plus $5 \mathrm{~m}$ above and below this depth. This was done considering that the effective fishing height of the trawl is expected to be wider than the actual trawl opening (Doray et al. 2010). Total NASC values $\left(\mathrm{NASC}_{\mathrm{t}}\right.$ ) recorded at trawl station $\mathrm{t}$ were calculated as the total NASC values of the ESUs along the haul tracks.

To transform catch data to equivalent acoustic data, equivalent NASC (Simmonds and MacLennan 2005), $\operatorname{ENASCs}(t)$, were computed for each of the main species $(s)$ caught at station $t$ (Doray et al. 2010) by

$$
\operatorname{ENASCs}(t)=\frac{4 \pi N_{s}(t) \sigma_{b s}}{A}
$$

where $A$ is the area swept during a haul (in square nautical miles), $N_{s}$ is the (estimated) catch in numbers of individuals of species $\mathrm{s}$ at station $\mathrm{t}$ and $\sigma_{\mathrm{bs}}$ is the theoretical backscattering cross section (MacLennan et al. 2002) of species s. Values of $\sigma_{\mathrm{bs}}$ were computed from $\sigma_{\mathrm{bs}}=10^{\mathrm{TS} / 10}$, where target strength (TS) is the theoretical (literature) value of target strength by species. The $b_{20}$ used were $-71.2 \mathrm{~dB}$ for anchovy and $-72.6 \mathrm{~dB}$ for sardine (Anonymous 2012).

The approach followed estimates trawl efficiency independently of the fish availability at sea. We assumed the value of NASC $(\mathrm{t})$ recorded on board during station $t$ to be a reasonable estimate of the true density of fish encountered along the trawl track

$$
\operatorname{ENASCs}(\mathrm{t})=\mathrm{Q}[\mathrm{NASC}(\mathrm{t})]^{\mathrm{b}}
$$

where $Q$ is the trawl efficiency, defined as the proportion of animals within the swept volume captured by the trawl of vessel and $b$ is a parameter. $Q$ and $b$ were estimated by $\log$ transformation of the equation. If $b$ is 1 , the relationship between catch and density is linear; for $b<1$ it is non-linear. Hauls by day and night were analysed separately, as were the monospecific hauls of anchovy, while hauls of sardine are not presented here because they were very few in number.

\section{Sensitivity analysis}

We examined the possible error that could be introduced into the biomass estimations by acoustics because of inappropriate time of sampling and the subsequent error in the estimation of the mean length. For this purpose we assessed the subsequent changes in biomass estimations taking into account an increase/decrease in the mean length by 1 and $2 \mathrm{~cm}$, based on the estimated maximum difference of mean TL between day and night. Similarly, a sensitivity analysis was applied concerning another big source of error in acoustic estimates: the effect of $b_{20}$ in the TS equation (Simmonds and MacLennan 2005) and the subsequent biomass estimates. The relationship between TS and TL,

$$
\mathrm{TS}=\mathrm{a} \log (\mathrm{TL})+\mathrm{b}
$$


TABLE 3. - ANOVA table for diversity indices of each group. For each index the test results and the p-value (in brackets) are presented. Significant probabilities are in bold. Empty cells represent groups with only one species or those groups in which only anchovy and sardine were caught. S, number of species per haul; d, Margalef species richness; J, evenness index; H', Shannon-Wiener diversity index; $1-\lambda$, Simpson index.

\begin{tabular}{|c|c|c|c|c|c|}
\hline Groups & S & d & $J^{\prime}$ & $\mathrm{H}^{\prime}$ & $1-\lambda$ \\
\hline \multicolumn{6}{|l|}{ Aegean Sea } \\
\hline 1995 Summer & - & - & - & - & - \\
\hline 1996 Summer & - & - & - & - & - \\
\hline 2003 Summer & $3(0.333)$ & $0.09(0.818)$ & $7.34(0.225)$ & $10.32(0.192)$ & $30.81(0.113)$ \\
\hline 2004 Summer & $0.75(0.545)$ & $0.78(0.540)$ & $7.34(0.194)$ & $0.59(0.584)$ & $0.51(0.605)$ \\
\hline 2005-1 Summer & $0.33(0.667)$ & $0.77(0.530)$ & $0.87(0.450)$ & $2.19(0.277)$ & $1.05(0.413$ \\
\hline 2005-2 Summer & $0.33(0.666)$ & $0.01(0.946)$ & $282.22(0.037)$ & $99.24(0.063)$ & $255.18(0.040)$ \\
\hline 2005-3 Summer & $0.33(0.667)$ & $0.81(0.532)$ & $34.12(0.107)$ & $46.02(0.093)$ & $33.21(0.109)$ \\
\hline 2005-4 Summer & equal No of species & equal No of species & $8.27(0.213)$ & $9.24(0.202)$ & $20.07(0.139)$ \\
\hline 2006-1 Summer & - & - & - & - & - \\
\hline 2006-2 Summer & equal No of species & equal No of species & $34.11(0.107)$ & $109.47(0.060)$ & $30.72(0.113)$ \\
\hline 2006-3 Summer & - & - & - & - & - \\
\hline 2006-4 Summer & - & - & - & - & - \\
\hline 2006-5 Summer & $0.33(0.667)$ & $0.04(0.882)$ & $6.01(0.246)$ & $2.44(0.367)$ & $2.12(0.383)$ \\
\hline 2006-6 Summer & - & - & - & - & - \\
\hline 2008-1 Summer & - & - & - & - & - \\
\hline 2008-2 Summer & $2.25(0.272)$ & $2.07(0.286)$ & $0.02(0.893)$ & $0.13(0.751)$ & $0.13(0.749)$ \\
\hline 2008-3 Summer & $0.33(0.667)$ & $1.57(0.428)$ & $1.34(0.454)$ & $7.68(0.220)$ & $2.18(0.378)$ \\
\hline 2008-4 Summer & - & - & - & - & - \\
\hline 2007 Summer & $1.31(0.282)$ & $1.02(0.339)$ & $0.01(0.928)$ & $0.01(0.928)$ & $0.15(0.708)$ \\
\hline 2008 Summer & $6.44(\mathbf{0 . 0 4 0})$ & $5.83(\mathbf{0 . 0 4 6})$ & $47.72(\mathbf{0 . 0 0 2})$ & $0.15(0.706)$ & $0.55(0.484)$ \\
\hline 2007 Winter & $5.48(0.051)$ & $9.39(0.061)$ & $3.01(0.110)$ & $1.88(0.197)$ & $2.28(0.159)$ \\
\hline 2009 Winter & $1.8(0.216)$ & $0.65(0.444)$ & $3.03(0.119)$ & $3.44(0.101)$ & $5.63(0.055)$ \\
\hline \multicolumn{6}{|l|}{ Western driatic Sea } \\
\hline 2009-1 Summer & $1.80(0.312)$ & $0.98(0.427)$ & $0.60(0.519)$ & $1.20(0.387)$ & $0.80(0.465)$ \\
\hline 2009-2 Summer & $0.00(1.000)$ & $0.04(0.870)$ & $6.15(0.131)$ & $6.87(0.120)$ & $5.85(0.137)$ \\
\hline 2009-3 Summer & $0.00(0.083)$ & $0.00(0.121)$ & $1.08(0.408)$ & $3.17(0.217)$ & $2.06(0.288)$ \\
\hline 2009-4 Summer & $0.00(0.083)$ & $7.47(0.112)$ & $4.13(0.179)$ & $6.79(0.121)$ & $4.50(0.168)$ \\
\hline 2009-5 Autumn & $9.00(0.095)$ & $1.12(0.400)$ & $0.164(0.725)$ & $0.50(0.554)$ & $0.59(0.522)$ \\
\hline 2009-6 Autumn & $0.00(1.000)$ & $0.01(0.929)$ & $0.51(0.551)$ & $0.38(0.600)$ & $0.39(0.595)$ \\
\hline 2010-7 Summer & - & - & - & - & - \\
\hline 2010-8 Summer & - & - & - & - & - \\
\hline \multicolumn{6}{|l|}{ Strait of Sicily } \\
\hline 2010-1 Summer & $0.20(0.699)$ & $0.25(0.666)$ & $3.42(0.205)$ & $1.05(0.414)$ & $1.69(0.323)$ \\
\hline 2010-2 Summer & $0.50(0.553)$ & $0.14(0.742)$ & $6.23(0.130)$ & $2.38(0.263)$ & $4.12(0.179)$ \\
\hline \multicolumn{6}{|l|}{ Iberian coast } \\
\hline 2009 Summer & $1.13(0.349)$ & $0.61(0.477)$ & $1.75(0.256)$ & $1.44(0.296)$ & $1.78(0.253)$ \\
\hline
\end{tabular}

is fundamental in fisheries acoustics. $b_{20}$ is the value of constant $b$ when the slope $a$ is forced to equal 20 . The latter is a common practice because a) the estimated values of the constant a are not significantly different from 20, as backscattering energy is expected to be proportional to the horizontal cross section area of fish organs (mainly swimbladder) that contribute to echo and b) it allows comparisons between several TS estimations (Simmonds and MacLennan 2005). As TS is a stochastic variable, the range of $b_{20}$ used for anchovy and sardine in the different areas is quite wide i.e. for sardine ranges from -70.51 to $72.6 \mathrm{~dB}$ and for anchovy from -71.2 to $75.3 \mathrm{~dB}$ (Anonymous 2012). Here within the terms of sensitivity analysis we applied $\pm 0.5 \mathrm{~dB}$ and $\pm 1 \mathrm{~dB}$ differences in the currently applied TS values and compared estimates with the trawl efficiency respective results.

\section{RESULTS}

\section{Species composition}

Comparisons concerning the diversity indices between the pairs of hauls are presented in Table 3, while the comparisons per survey (i.e. all haul groups of each survey are merged) are presented in Table 4. In general no differences were found for the diversity indices, with only one exception in which more species were caught at night in small numbers of individuals.

\section{Length frequency comparisons}

In the Aegean Sea, the comparisons of the anchovy length frequency distribution between day and night, estimated per haul group, revealed that in 5 out of 16 cases bigger individuals were caught at night than during the day, in 7 out of 16 cases bigger individuals were caught during the day than at night and in 4 cases no difference was found. In the western Adriatic Sea in 2 out of 8 cases bigger individuals were caught at night than during the day; in 5 out of 8 cases bigger individuals were caught during the day than at night and in 1 case no difference was estimated. In the Strait of Sicily in 1 out of the 2 cases bigger individuals were caught during the day, while the other case indicated no difference between daytime and night-time. Overall, in 13 cases bigger individuals were caught during day, in 7 cases bigger individuals were caught at night, and in 6 cases no difference was found (Table 5). 
TABLE 4. - ANOVA table for diversity indices estimated per survey (i.e. merged haul groups). For each index the test results and the p-value (in brackets) are presented. Significant probabilities are in bold. Empty cells represent surveys with only one species or those surveys where only anchovy and sardine were caught. S, number of species per haul; J, evenness index; H', Shannon-Wiener diversity index; $1-\lambda$, Simpson index.

\begin{tabular}{|c|c|c|c|c|c|}
\hline Survey & S & $\mathrm{D}$ & $\mathrm{J}^{\prime}$ & $\mathrm{H}^{\prime}$ & $1-\lambda$ \\
\hline \multicolumn{6}{|l|}{ Aegean Sea } \\
\hline 1995 Summer & - & - & - & - & - \\
\hline 1996 Summer & - & - & - & - & - \\
\hline 2003 Summer & $3.00(0.333)$ & $0.90(0.818)$ & $7.34(0.225)$ & $10.32(0.192)$ & $30.81(0.113)$ \\
\hline 2004 Summer & $0.75(0.545)$ & $0.78(0.540)$ & $0.29(0.684)$ & $0.001(0.979)$ & $1.08(0.487)$ \\
\hline 2005 Summer & $0.47(0.505)$ & $0.35(0.568)$ & $1.05(0.327)$ & $0.51(0.489)$ & $0.6(0.454)$ \\
\hline 2006 Summer & $2.34(0.150)$ & $1.62(0.226)$ & $1.33(0.269)$ & $2.37(0.147)$ & $2.69(0.124)$ \\
\hline 2008 Summer & $1.15(0.363)$ & $1.84(0.220)$ & $0.31(0.744)$ & $0.52(0.611)$ & $0.38(0.698)$ \\
\hline 2007 Summer & $1.31(0.282)$ & $1.02(0.339)$ & $0.01(0.928)$ & $0.01(0.928)$ & $0.15(0.708)$ \\
\hline 2008 Summer & $6.44(\mathbf{0 . 0 4 0})$ & $5.83(\mathbf{0 . 0 4 6 4})$ & $47.72(\mathbf{0 . 0 0 2})$ & $0.15(0.706)$ & $0.55(0.484)$ \\
\hline 2007 Winter & $5.48(0.051)$ & $9.39(0.061)$ & $3.01(0.110)$ & $1.88(0.197)$ & $2.28(0.159)$ \\
\hline 2009 Winter & $1.80(0.216)$ & $0.65(0.444)$ & $3.03(0.119)$ & $3.44(0.106)$ & $5.63(0.055)$ \\
\hline \multicolumn{6}{|l|}{ Western Adriatic Sea } \\
\hline 2009-12 Summer & $0.57(0.492)$ & $0.25(0.642)$ & $0.22(0.661)$ & $0.04(0.844)$ & $0.14(0.732)$ \\
\hline 2010- 78 Summer & - & - & - & - & - \\
\hline 2009-56 Summer & $0.92(0.391)$ & $0.35(0.584)$ & $0.20(0.676)$ & $0.40(0.559)$ & $0.44(0.545)$ \\
\hline 200934 Summer & $5.33(0.082)$ & $4.58(0.099)$ & $3.99(0.116)$ & $0.01(0.064)$ & $5.89(0.072)$ \\
\hline \multicolumn{6}{|l|}{ Strait of Sicily } \\
\hline 2010 Summer & $0.001(1.000)$ & $0.032(0.867)$ & $6.51(0.063)$ & $2.47(0.191)$ & $4.25(0.108)$ \\
\hline \multicolumn{6}{|l|}{ Iberian coast } \\
\hline
\end{tabular}

Results of the length frequency comparisons per survey were quite similar. Anchovy comparisons in the Aegean Sea revealed that in 2 out of 10 cases bigger individuals were caught at night than during the day, in 4 out of 10 cases bigger individuals were caught during the day than at night and in 4 cases no difference was found. In the western Adriatic Sea in 1 out of 4 cases bigger individuals were caught at night than during the day, whereas in 3 out of 4 cases bigger individuals were caught during the day than at night. In the Strait of Sicily results indicated that bigger individuals were caught during the day than at night. Overall, in 3 surveys bigger individuals were caught at night, in 8 surveys bigger individuals were caught during the day, and in 4 surveys no difference was found (Table 6).

The case of sardine presented quite similar results. In the Aegean Sea the comparisons of length frequency distribution per haul group revealed that in 2 out of 14 cases bigger individuals were caught at night than during the day; in 6 out of 14 cases bigger individuals were caught during the day than at night; and in 6 cases no difference was estimated. In the western Adriatic Sea, in 1 out of 6 cases bigger individuals were caught at night than during the day; in 2 out of 6 cases bigger individuals were caught during the day than at night, while in 3 cases no difference was found. In the Strait of Sicily, no difference was found between day and night. Overall, in 3 cases bigger individuals were caught at night, in 10 cases bigger individuals caught during the day, while in 10 cases no difference was found (Table 7).

The results per survey were quite similar. In the Aegean Sea, the comparisons of the length frequency distribution concerning sardine revealed that in 5 out of 10 cases bigger individuals were caught during the
TABLE 5. - Anchovy. Results of the Kruskal-Wallis test (K-W) comparisons in each pair of hauls applied to anchovy length frequency distributions. D, Day; N, Night; ND, No difference.

\begin{tabular}{|c|c|c|c|c|}
\hline Area & Groups & Results & $\mathrm{K}-\mathrm{W}$ & $\mathrm{p}$-value \\
\hline \multicolumn{5}{|c|}{ Aegean Sea } \\
\hline & 1995 Summer & $\mathrm{N}>\mathrm{D}$ & 22.35 & 0.000 \\
\hline & 1996 Summer & $\mathrm{D}>\mathrm{N}$ & 92.60 & 0.000 \\
\hline & 2003 Summer & ND & 0.26 & 0.612 \\
\hline & 2005-1 Summer & ND & 0.01 & 0.932 \\
\hline & 2005-2 Summer & $\mathrm{D}>\mathrm{N}$ & 24.18 & 0.000 \\
\hline & 2005-3 Summer & $\mathrm{D}>\mathrm{N}$ & 27.36 & 0.000 \\
\hline & 2006-1 Summer & ND & 1.57 & 0.210 \\
\hline & 2006-2 Summer & $\mathrm{N}>\mathrm{D}$ & 16.72 & 0.000 \\
\hline & 2006-3 Summer & $N>D$ & 23.99 & 0.000 \\
\hline & 2006-4 Summer & $\mathrm{D}>\mathrm{N}$ & 23.99 & 0.002 \\
\hline & 2008-1 Summer & $N>D$ & 45.58 & 0.000 \\
\hline & 2008-2 Summer & $\mathrm{N}>\mathrm{D}$ & 6.87 & 0.009 \\
\hline & 2007 Summer & $\mathrm{D}>\mathrm{N}$ & 34.23 & 0.000 \\
\hline & 2007 Winter & ND & 0.03 & 0.864 \\
\hline & 2008 Summer & $\mathrm{D}>\mathrm{N}$ & 16.97 & 0.000 \\
\hline & 2009 Winter & $\mathrm{D}>\mathrm{N}$ & 25.52 & 0.000 \\
\hline \multicolumn{5}{|c|}{ Western Adriatic Sea } \\
\hline & 2009-1 Summer & $\mathrm{D}>\mathrm{N}$ & 50.39 & 0.000 \\
\hline & 2009-2 Summer & $\mathrm{D}>\mathrm{N}$ & 47.19 & 0.000 \\
\hline & 2009-3 Summer & $\mathrm{D}>\mathrm{N}$ & 64.16 & 0.000 \\
\hline & 2009-4 Summer & ND & 21.52 & 0.227 \\
\hline & 2009-5 Autumn & $\mathrm{N}>\mathrm{D}$ & 35.62 & 0.010 \\
\hline & 2009-6 Autumn & $\mathrm{N}>\mathrm{D}$ & 54.87 & 0.000 \\
\hline & 2010-7 Summer & $\mathrm{D}>\mathrm{N}$ & 156.53 & 0.000 \\
\hline & 2010-8 Summer & $\mathrm{D}>\mathrm{N}$ & 115.12 & 0.000 \\
\hline \multicolumn{5}{|c|}{ Strait of Sicily } \\
\hline & 2010-1 Summer & $\mathrm{D}>\mathrm{N}$ & 75.22 & 0.001 \\
\hline & 2010-2 Summer & ND & 2.64 & 0.104 \\
\hline
\end{tabular}

day than at night; and in five cases no difference was found. In the western Adriatic Sea, in 1 case bigger individuals were caught at night, in 1 case bigger individuals were caught during the day and in the third case no difference was found. In the Strait of Sicily, the overall comparison indicated that bigger individuals were caught during the day than at night. 
TABLE 6. - Anchovy. Results of the Kruskal-Wallis test (K-W) comparisons in each survey by merging all the pairs of hauls applied to anchovy length frequency distributions. D, day; N, night; ND, no difference.

\begin{tabular}{llccc}
\hline Area & Survey & Results & K-W & p-value \\
\hline Aegean Sea & & & \\
1995 Summer & N $>$ D & 22.35 & 0.000 \\
1996 Summer & D $>$ N & 92.60 & 0.000 \\
2003 Summer & ND & 0.26 & 0.612 \\
2005 Summer & ND & 0.19 & 0.659 \\
2006 Summer & ND & 0.12 & 0.727 \\
2008 Summer & N $>$ D & 16.97 & 0.000 \\
2007 Summer & D $>$ N & 34.23 & 0.000 \\
2007 Winter & ND & 0.03 & 0.864 \\
2008 Summer & D $>$ N & 16.97 & 0.000 \\
2009 Winter & D $>$ N & 25.52 & 0.000 \\
Western Adriatic Sea & & & \\
2009-12 Summer & D $>$ N & 14.74 & 0.000 \\
2009-34 Summer & D $>$ N & 11.25 & 0.001 \\
2009-56 Summer & N $>$ D & 14.72 & 0.000 \\
2010-78 Summer & D $>$ N & 122.55 & 0.000 \\
Strait of Sicily Summer & D $>$ N & 16.92 & 0.001 \\
2010 Summer & & & \\
\hline
\end{tabular}

TABLE 7. - Sardine. Results of the Kruskal-Wallis test (K-W) comparisons in each pair of hauls applied to sardine length frequency distributions. D, Day; N, Night; ND, No difference.

\begin{tabular}{|c|c|c|c|c|}
\hline Area & Groups & Results & $\mathrm{K}-\mathrm{W}$ & p-value \\
\hline \multicolumn{5}{|c|}{ Aegean Sea } \\
\hline & 1996 Summer & $\mathrm{D}>\mathrm{N}$ & 64.71 & 0.000 \\
\hline & 2003 Summer & ND & 0.73 & 0.393 \\
\hline & 2004 Summer & $\mathrm{D}>\mathrm{N}$ & 9.30 & 0.002 \\
\hline & 2005-1 Summer & $\mathrm{D}>\mathrm{N}$ & 25.96 & 0.000 \\
\hline & 2005-2 Summer & $\mathrm{D}>\mathrm{N}$ & 89.95 & 0.000 \\
\hline & 2005-3 Summer & $\mathrm{N}>\mathrm{D}$ & 48.62 & 0.000 \\
\hline & 2006-1 Summer & ND & 0.72 & 0.395 \\
\hline & 2006-2 Summer & ND & 0.06 & 0.812 \\
\hline & 2006-3 Summer & ND & 1.13 & 0.289 \\
\hline & 2008-1 Summer & $N>D$ & 3.30 & 0.069 \\
\hline & 2007 Summer & $\mathrm{D}>\mathrm{N}$ & 2.74 & 0.098 \\
\hline & 2007 Winter & ND & 0.09 & 0.762 \\
\hline & 2008 Summer & ND & 0.01 & 0.906 \\
\hline & 2009 Winter & $\mathrm{D}>\mathrm{N}$ & 22.57 & 0.000 \\
\hline \multicolumn{5}{|c|}{ Western Adriatic Sea } \\
\hline & 2009-1 Summer & $\mathrm{D}>\mathrm{N}$ & 32.54 & 0.007 \\
\hline & 2009-2 Summer & $\mathrm{D}>\mathrm{N}$ & 64.72 & 0.000 \\
\hline & 2009-3 Summer & ND & 0.69 & 0.408 \\
\hline & 2009-4 Summer & ND & 1.97 & 0.160 \\
\hline & 2009-5 Autumn & ND & 14.10 & 0.735 \\
\hline & 2009-6 Autumn & $N>D$ & 56.28 & 0.000 \\
\hline \multicolumn{5}{|c|}{ Strait of Sicily } \\
\hline & 2010-1 Summer & $\mathrm{D}>\mathrm{N}$ & 37.50 & 0.000 \\
\hline & 2010-2 Summer & $\mathrm{D}>\mathrm{N}$ & 8.31 & 0.004 \\
\hline \multicolumn{5}{|c|}{ Iberian coast } \\
\hline & 2009 -1 Summer & ND & 2.91 & 0.106 \\
\hline
\end{tabular}

Overall, in 1 survey bigger individuals were caught at night, in 7 surveys bigger individuals were caught during the day, and in 7 surveys no difference was found (Table 8).

The results of paired-sample comparison analysis showed no differences between day and night in the examined parameters of the length frequency distribution for the pooled groups (Table 9) or in the sampling area (not presented here). Thus, the analysis revealed that the differences indicated by the ANOVA approach were random and non-systematic.
TABLE 8. - Sardine. Results of the Kruskal-Wallis test (K-W) comparisons in each survey by merging all the pairs of hauls applied to sardine length frequency distributions. D, Day; N, Night; ND, No difference.

\begin{tabular}{|c|c|c|c|c|}
\hline Area & Survey & Results & K-W & p-value \\
\hline \multicolumn{5}{|c|}{ Aegean Sea } \\
\hline & 1995 Summer & $\mathrm{D}>\mathrm{N}$ & 64.71 & 0.000 \\
\hline & 2003 Summer & ND & 0.73 & 0.393 \\
\hline & 2004 Summer & $\mathrm{D}>\mathrm{N}$ & 9.30 & 0.002 \\
\hline & 2005 Summer & $\mathrm{D}>\mathrm{N}$ & 6.30 & 0.012 \\
\hline & 2006 Summer & $\mathrm{D}>\mathrm{N}$ & 4.24 & 0.039 \\
\hline & 2008 Summer & ND & 3.30 & 0.069 \\
\hline & 2007 Summer & ND & 2.74 & 0.098 \\
\hline & 2007 Winter & ND & 0.09 & 0.762 \\
\hline & 2008 Summer & ND & 0.01 & 0.906 \\
\hline & 2009 Winter & $\mathrm{D}>\mathrm{N}$ & 22.57 & 0.000 \\
\hline \multicolumn{5}{|c|}{ Western Adriatic Sea } \\
\hline & 2009-12 Summer & $\mathrm{D}>\mathrm{N}$ & 13.93 & 0.000 \\
\hline & 2009-34 Summer & ND & 0.59 & 0.809 \\
\hline & 2009-56 Autumn & $\mathrm{N}>\mathrm{D}$ & 7.25 & 0.007 \\
\hline \multicolumn{5}{|c|}{ Strait of Sicily } \\
\hline & 2010 Summer & $\mathrm{D}>\mathrm{N}$ & 27.55 & 0.000 \\
\hline \multicolumn{5}{|c|}{ Iberian coast } \\
\hline & 2009 Summer & ND & 2.91 & 0.106 \\
\hline
\end{tabular}

TABLE 9. - Paired-sample comparison analysis for average, min, max, range, Standard skewness and standard kurtosis. $t$ test statistics and sign test are presented for the cases that meet the assumptions of the $t$ test; otherwise only sign tests are presented. In the first row the sample test statistic is presented, while in the second row the possibility is presented in brackets.

\begin{tabular}{lcccccc}
\hline & Average & Min & Max & Range & $\begin{array}{c}\text { Stnd. } \\
\text { skewness }\end{array}$ & $\begin{array}{c}\text { Stnd. } \\
\text { kurtosis }\end{array}$ \\
\hline Anchovy & & & & & & \\
$t$ test & 2.006 & 2.023 & -0.465 & -2.019 & & 0.141 \\
& $(0.065)$ & $(0.054)$ & $(0.646)$ & $(0.058)$ & & $(0.889)$ \\
sign test & 0.981 & 1.492 & 0.213 & 1.429 & 1.765 & 1.600 \\
& $(0.327)$ & $(0.136)$ & $(0.831)$ & $(0.153)$ & $(0.078)$ & $(0.110)$ \\
Sardine & & & & & & \\
$t$ test & 1.080 & 1.693 & -0.074 & -1.027 & & 0.583 \\
& $(0.292)$ & $(0.105)$ & $(0.942)$ & $(0.315)$ & & $(0.566)$ \\
sign test & 1.485 & 1.455 & 0.001 & 0.001 & 0.001 & 0.417 \\
& $(0.137)$ & $(0.146)$ & $(0.999)$ & $(0.999)$ & $(0.999)$ & $(0.677)$ \\
\hline
\end{tabular}

\section{Trawl efficiency during daytime and night-time}

The trawl efficiency estimates were based on the relationship $\log (\mathrm{ENASC})=\log (\mathrm{Q})+\mathrm{b}[\mathrm{NASC}$. The average trawl efficiency coefficient at night was 0.28 for the anchovy-dominated hauls and 0.25 for all species, while the regression between $\log ($ ENASC) and $\log$ (NASC) was not significant $(\mathrm{p}>>0.05)$ for the daytime hauls in either case (Table 10, Fig. 3). The estimated exponent $\mathrm{b}$ was close to 1 ( 0.88 for anchovy and 0.84 for all species), indicating a linear relationship between ENASC and NASC (e.g. the catch is proportional to fish density). Although no significant relationship was found for day time, it should be noted that the available daytime data were rather limited, so more data or targeted experiments are required to obtain safe conclusions.

\section{Sensitivity analysis}

Higher mean TL estimates from the catch result in overestimation of the total biomass and similarly lower 
TABLE 10. - Estimates of trawl efficiency coefficients (Q) and exponents (b) from the models relating ENASC derived from trawl catches to observed NASC, along with the $R^{2}$ representing the variance explained by the model, with standard error values in parenthesis. D, daytime; $\mathrm{N}$, night-time; $\mathrm{p}_{\mathrm{F}}$, significance of $\mathrm{F}$ statistics for the regression.

\begin{tabular}{lccccc}
\hline Species & No of hauls & Diel period & b estimate & $\log (\mathrm{Q})$ estimate & $R^{2}$ \\
\hline Anchovy & 9 & $\mathrm{D}$ & & Non-significant estimates \\
$\mathrm{p}_{\mathrm{F}}=0.168$ & 0.896 \\
Anchovy & 16 & $\mathrm{~N}$ & $0.88(0.11)$ & $-0.28(0.32)$ & $\begin{array}{c}\text { Non-significant estimates } \\
\mathrm{p}_{\mathrm{F}}=0.277\end{array}$ \\
All Species & 13 & $\mathrm{D}$ & & 0.84 \\
All Species & 23 & $\mathrm{~N}$ & $0.83(0.11)$ & $-0.25(0.32)$ & $\mathrm{p}_{\mathrm{F}}<<0.001$ \\
\hline
\end{tabular}

Day

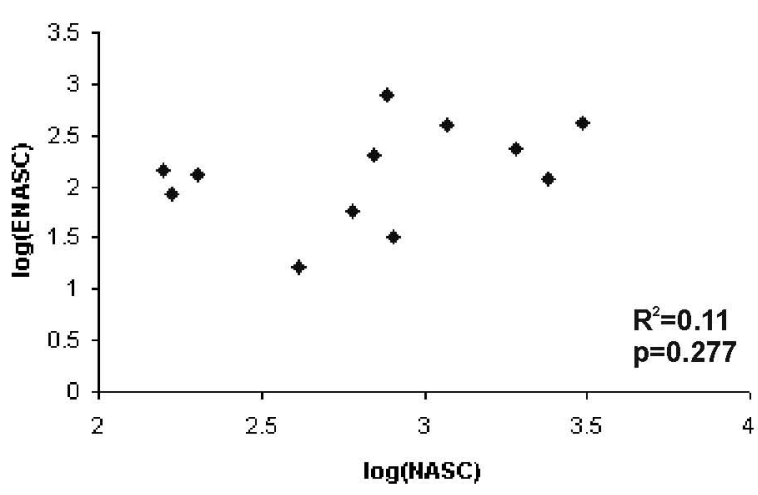

Night

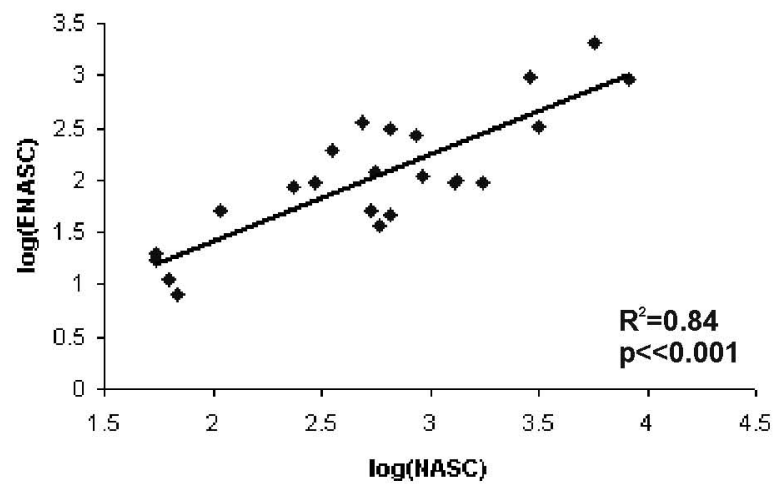

FIG. 3. - Relationship between total ENASCs per haul and total NASCs per haul, during daytime and night-time, combined for all species.

TL result in underestimation of the total biomass. Results concerning anchovy and sardine estimates in the Aegean Sea are presented in Table 11. Results concerning the effect of changes in the $b_{20}$ coefficient of the TS equation are also presented in Table 11. A 1-cm difference in TL, the most usual difference observed between day and night, resulted in an 8\%-10\% difference in biomass, whereas a $2-\mathrm{cm}$ difference, which is the highest significant difference estimated, resulted in a $14 \%-15 \%$ difference in the biomass. This range of error in the biomass was comparable to an approximate difference of $0.5 \mathrm{~dB}$ in the TS estimated function.

\section{DISCUSSION}

Allocation of the acoustic records to species is the most essential process for the successful application of

TABLE 11. - The percentages of change in the biomass estimations when the Total length increases by $1(\mathrm{TL}+1)$ or by $2(\mathrm{TL}+2) \mathrm{cm}$, or decreases by $1(\mathrm{TL}-1)$ or by 2 (TL-2) $\mathrm{cm}$. The estimated percentages of variation in the biomass estimation if $b_{20}$ changes by 0.5 and $1 \mathrm{~dB}$ are also presented.

\begin{tabular}{lcc}
\hline & Anchovy & Sardine \\
\hline $\mathrm{TL}+1$ & $+9.69 \%$ & $+7.61 \%$ \\
$\mathrm{TL}+2$ & $+14.53 \%$ & $+13.77 \%$ \\
$\mathrm{TL}-1$ & $-10.51 \%$ & $-9.01 \%$ \\
$\mathrm{TL}-2$ & $-14.94 \%$ & $-14.56 \%$ \\
$b_{20} \pm 0.5$ & $\pm 12.56 \%$ & $\pm 12.36 \%$ \\
$b_{20} \pm 1$ & $\pm 21.96 \%$ & $\pm 23.36 \%$ \\
\hline
\end{tabular}

acoustic surveys and is closely associated with haul operation. For this purpose, obtaining representative samples of the pelagic assemblage using appropriate trawl hauls is one of the main targets in any acoustic survey, associated with one of the most usual sources of error in biomass assessments by means of acoustics. Time of sampling is among the main factors that could cause bias in the haul catch. The bias could be even more pronounced in small pelagics, mainly because they are known to show diel vertical migration, form dense schools during daytime, and disperse at loose aggregations close to the surface during night-time (Woodhead 1966, Massè 1996, Giannoulaki et al. 1999, Zwolinski et al. 2007, Tsagarakis et al. 2012). Time of fishing might also be related to trawl selectivity, increasing the possibility for the smaller individuals to escape from the net during the daytime because of the optical contact with the trawl and the large mesh size of the net at the front of the gear, while the absence of this contact during the night-time supports "blind", random selection sampling. In addition, the dispersing, loose aggregations of fish at night can facilitate obtaining more random and more representative sampling.

In order to determine whether there is a difference in the catch during daytime and night-time sampling in the MEDIASs, comparisons were made using paired groups of daytime and night-time hauls from different parts of the Mediterranean Sea. Hauls were selected or specifically conducted using a common protocol. The 
differences in species composition were examined using certain diversity indices, while differences in the size of the specimens were examined by comparing the length-frequency distribution. The latter comparisons focused on the two main target species in the MEDIASs: anchovy and sardine.

In general, no significant differences were estimated in the diversity indices, with the exception of one case, in which more species were caught at night, indicating that qualitatively the two sampling periods are similar. In addition, some significant differences were found only for those indices that are more susceptible to the number of individuals caught, whereas no significant differences were observed in those indices that were standardized by the number of specimens caught, such as $H^{\prime}$ and Simpson 1- $\lambda$. The absence of any difference in the diversity indices between day and night implies that day and night sampling could result in equally representative samples of species composition of the pelagic community.

The length-frequency distribution analysis of certain pair groups indicated differences between day and night but no trends in these differences were observed. The paired-sample comparison analysis verified that the estimated differences between day and night were rather random and not consistent, indicating overall a non-systematic difference regarding the length estimations.

Moreover, a change in the mean length by 1 or 2 $\mathrm{cm}$ results in a smaller or similar percentage of underor overestimation (e.g. less than 10\%) of the biomass compared with a change of $0.5 \mathrm{~dB}$ in the $b_{20}$ coefficient of the TS equation, which is another important source of error that results in an error of about $13 \%$. The last level of error is expected because of the stochastic nature of TS and the use general and non-species-specific equations.

The analysis of the trawl efficiency from the available data indicated that trawling during night was proportional to fish density (i.e. b close to 1 ) while this was not the case for trawling during the day (i.e. the relationship was not significant). This implies the occurrence of a more representative (less selective) and less biased sampling at night than during the day, at least for the examined target species: anchovy and sardine. This is an issue that needs further investigation and targeted experiments, because the data used-especially those involved day time sampling of sardine-were limited. On the other hand, simultaneous fishing and acoustic recording during the daytime has the advantage that targeted trawling can be conducted and the insonified fish schools can be directly associated with the catches. Therefore, daytime sampling is essential and practically obligatory in order to identify specific acoustic targets and fish schools (Simmonds and MacLennan 2005).

Significant issues directly related to research surveys at sea are the duration and cost of the survey, which increases substantially with survey duration.
The results of the present study suggest that flexible sampling strategies could be adopted depending on the needs of each acoustic survey. Specifically, according to the results of the present study, daytime trawling can be combined with night-time trawling, thus reducing the survey time. Moreover, since nighttime sampling seems to provide a more representative length-frequency distribution, merging results from night-time and daytime sampling can mitigate possible errors. Furthermore, if we consider the benefits that can be obtained from such a flexible sampling strategy, the subsequent error seems small compared with other common sources of error in acoustic estimates.

\section{ACKNOWLEDGEMENTS}

This study was supported by the Commission of the European Union through the Project "AcousMed": Harmonization of the acoustic data in the Mediterranean, MARE/2009/09 and the MEDIAS workshops of the DCF. We thank the captains and crews of the RVs Philia, Cornide de Saavedra, Maria Grazia and Dallaporta and all of the scientists on board for their assistance during the surveys.

\section{REFERENCES}

Anonymous 2012. Harmonization of the acoustic data in the Mediterranean 2002-2006. Final Report. MARE/2009/09, 212 pp.

Azzali M., Buracchi G., Conti S., Gambetti S., Luna M. 1985. Relationship between the forms of pelagic fish distribution and nycthemeral periods. A tentative model of behaviour. Oebalia 11: 471-488.

Basilone G., Guisande C., Patti B., Mazzola S., Cuttitta A., Bonanno A., Kallianiotis A. 2004. Linking habitat conditions and growth in the European anchovy (Engraulis encrasicolus). Fish. Res. 68(1-3): 9-19.

Clarke K.R., Warwick R.M. 1994. Change in marine communities: an approach to statistical analysis and interpretation. Natural Environment Research Council, UK

Doray M., Mahevas S., Trenkel V.M. 2010. Estimating gear efficiency in a combined acoustic and trawl survey, with reference to the spatial distribution of demersal fish. ICES J. Mar. Sci. 67: 668-676.

Fréon P, Misund O.E. 1999. Dynamics of Pelagic Fish Distribution and Behaviour: Effects on Fisheries and Stock Assessment. Blackwell Science Ltd, Oxford, 360 pp.

Giannoulaki M., Machias A., Tsimenides N. 1999. Ambient luminance and vertical migration of the sardine Sardina pilchardus. Mar. Ecol. Prog. Ser. 178: 29-38.

ICES 2005. Report of the Working Group on Fisheries Acoustics Science and Technology (WGFAST), 19-22 April 2005, Rome, Italy. ICES CM 2005/B:05, 57 pp.

ICES 2009. Report of the working group on anchovy and sardine (WGANSA). 15-20 June 2009, Copenhagen, Denmark. ICES CM 2009/ACOM:13.

Iglesias M., Carrera P., Muino R. 2003. Spatio-temporal patterns and morphological characterisation of multispecies pelagic fish schools in the North-Western Mediterranean Sea. Aquat. Living Resour. 16: 541-548.

Karakassis I., Smith C.J., Eleftheriou A. 1996. Performance of neutral model analysis in a spatio-temporal series of macrobenthic replicates. Mar. Ecol. Prog. Ser. 137: 173-179.

MacLennan D., Fernandes P., Dalen J. 2002. A consistent approach to definitions and symbols in fisheries acoustics. ICES J. Mar. Sci. 59: 365-369.

Massé J. 1996. Acoustic observations in the Bay of Biscay: Schooling, vertical distribution, species assemblages and behaviour. Sci. Mar. 60(2): 227-234. 
SGMED 2009. Report of the SGMED-09-02 Working Group on the Mediterranean Part I. Scientific, Technical and Economic Committee for Fisheries (STECF), European Commission. In: Cardinale M, Cheilari A, Ratz HJ (eds.), 8-10 June 2009, Villasimius, Sardinia, Italy.

SGMED 2010. Report of the SGMED-10-02 Working Group on the Mediterranean Part I. Scientific, Technical and Economic Committee for Fisheries (STECF), European Commission. In: Cardinale M, Cheilari A, Ratz HJ (eds), 31 May-4 June 2010, Iraklion, Crete, Greece.

Simmonds E. J., MacLennan D.N. 2005. Fisheries Acoustics. Theory and Practice. Blackwell Publishing, Oxford, UK. 437 pp.

Stefanescu C., Rucabado J., Lloris D. 1992. Depth-size trends in western Mediterranean demersal deep-sea fishes. Mar. Ecol. Prog. Ser. 81: 205-213.

Szczucka J. 2000. Acoustically measured, diurnal vertical migration of fish and zooplankton in the Baltic Sea - seasonal variations. Oceanologia 42: 15-17.
Tsagarakis K., Giannoulaki M., Somarakis S., Machias A. 2012. Variability in positional, energetic and morphometric descriptors of European anchovy (Engraulis encrasicolus) schools related to patterns of diurnal vertical migration. Mar. Ecol. Prog. Ser. 446: 243-258.

Woodhead P.M.J. 1966. The behaviour of fish in relation to light in the sea. Oceanogr. Mar. Biol. Ann. Rev. 4: 337-403.

Zar J.H. 1984. Biostatistical analysis. Prentice-Hall, EnglewoodCliffs, NJ, 718 pp.

Zwolinski J., Morais A., Marques V., Stratoudakis Y., Fernandes P.G. 2007. Diel variation in the vertical distribution and schooling behaviour of sardine (Sardina pilchardus) off Portugal. ICES J. Mar. Sci. 64: 963-972.

Scient. ed.: S. Somarakis.

Received May 21, 2012. Accepted October 17, 2012.

Published online January 21, 2013 